Kaganga : Jurnal Pendidikan Sejarah dan Riset Sosial Humaniora.

Volume 1, Nomor 2, Desember 2018

e-ISSN : 2598-4934

$p-I S S N$ : 2621-119X

DOI : https://doi.org/10.31539/kaganga.v1i2.483

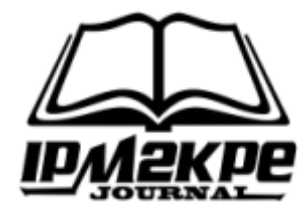

\title{
PERAN PONDOK PESANTREN \\ DALAM MENCEGAH PAHAM RADIKALISME DI KABUPATEN REJANG LEBONG
}

\author{
Syaiful Bahri \\ Dosen Institut Agama Islam Negeri (IAIN) Curup \\ hajisyaiful11@gmail.com
}

\begin{abstract}
ABSTRAK
Tujuan penelitian adalah untuk menelaah peran pondok pesantren dalam mencegah paham radikalisme di Kabupaten Rejang Lebong. Penelitian ini menggunakan pendekatan kualitatif dengan metode deskriftif kualitatif. Teknik pengumpulan data; wawancara, dokumentasi dan observasi. Hasil penelitian, dalam menjalankan kifrahnya pondok pesantren dalam beberapa dekade terakhir ini sering menjadi sasaran kecurigaan oleh banyak elemen masyakat dan penegak hukum, pondok pesantren tempat mendidik radikalisme dan terorisme. Berdasarkan hasil penelitian tidak ditemui pondok pesantren sebagai sumber radikalisme dan terorisme.Bahkan pondok pesantren berperan dalam mencegah paham radikalisme dan terorisme. Simpulan, peran pondok pesantren sangat efektif mencegah paham radikalisme dan teorisme melalui kontrol yang ketat terhadap civitas akademika pondok pesantren di Kabupaten Rejang Lebong.
\end{abstract}

Kata Kunci :Pondok Pesantren, Radikalisme, Terorisme

\begin{abstract}
The objective of the study was to analyze the role of islamic boarding school in preventing radicalism in Rejang Lebong regency. The study used qualitative approach with descriptive method. The data collection was done though interview, documentation and observation. The result showed that in playing the role, islamic boarding school recently became the target of people's distrust: this was the place of radicalism and terrorism. According to the analysis, there was no school found as the place of radicalism and terrorism. Some schools even actively prevent radicalism and terrorism effectively. In conclusion, the role of islamic boarding schools in Rejang Lebong to prevent radicalism and terrorism through the tight control was effective.
\end{abstract}

Keywords: Islamic Boarding School, Radicalism, Terrorism 


\section{PENDAHULUAN}

Pondok Pesantren adalah lembaga pendidikan tradisional Islam untuk mempelajari, memahami, mendalami, menghyati, dan mengamalkan ajaran Islam dengan menitik beratkan pentingnya moral keagamaan sebagai pedoman prilaku sehari-hari.Pondok Pesantren telah berperan dalam; transmisi ilmu-ilmu dan pengetahuan Islam, pemeliharaan Islam, dan reproduksi (calon-calon) Ulama.

Pondok Pesantren berfungsi diantaranya :Pertama, lembaga pendidikan. Pondok Pesantren menyelenggarakan pendidikan formal (madrasah, sekolah umum, dan perguruan tinggi) dan pendidikan nonformal (pengajaran kitab kuning dan madrasah diniyah).Kedua, lembaga penyiaran agama.Pondok Pesantren menyelenggarakan kegiatan majelis taklim (pengajian), diskusi keagamaan, dan sebagainya.Ketiga, Lembaga social ekonomi.Pondok Pesantren merespons, mengurangi pengangguran, memberantas kebodohan, menciptakan kehidupan yang sehat, dan sebagainya (Jamal, 2012).

Seiring dengan era globalisasi dan modrenisasi dewasa ini, fungsifungsi Pondok Pesantren (sebagai lembaga pendidikan, penyiaran agama dan sosial) semakin mengarah ke fungsi sosial ekonomi dan pendidikan.Pengembangan fungsi sosial ekonomi yang dilakukan Pondok Pesantren dimaksud didasari gagasan tentang kemadirian santri setelah menyelesaikan pendidikannya di Pondok Pesantren dan tuntutan bagi Pondok Pesantren untuk self supporting and self financing (Fatturrochman, 2018).

Dinamika Pondok Pesantren, jika dikomparasinya dengan lembaga pendidikan yang pernah muncul di Indonesia, merupakan sistem pendidikan yang tertua saat ini dan dianggap sebagai produk budaya Indonesia yang indigenous. Pendidikan Pondok Pesantren dimaksud "semula merupakan pendidikan agama Islam yang dimulai sejak munculnya masyarakat Islam di Nusantara pada abad ke-13"1 (Sulthon Masyhud dan Moh. Khusnurdilo, Manajemen Pondok Pesantren, 2003, hal.1). Walaupun lembaganya sangat sederhana pada waktu itu, pendidikan Pondok Pesantren merupakan satu-satunya lembaga pendidikan yang terstruktur, sehingga pendidikan ini sangat bergengsi, di lembaga inilah kaum muslimin Indonesia mendalami doktrin dasar Islam, khususnya menyangkut praktik kehidupan keagamaan (Sulthon, 2003).

Lembaga Pondok Pesantren berkembang dengan sebegitu cepat beriring dengan ciri khas kemandiriannya terutama dengan adanya "sikap non-kooperatif ulama terhadap kebijakan Politik Etis pemerintah Kolonial Belanda pada akhir abad ke 19"2 (Sulthon Masyhud dan Moh. Khusnurdilo, Manajemen Pondok Pesantren, 2003, hal.1). Menurut Brugmans (1987) misalnya 
"mencatat antara tahun 1900-1928 anak-anak usia 6-8 tahun yang bersekolah hanya 1,3 juta jiwa, padehal jumlah penduduk di pulau Jawa saja hingga tahun 1930 mencapai 41, 7 juta jiwa, berarti sekitar 97 persen penduduk Indonesia masih buta huruf'3 (Sulthon Msyhud dan Moh. Khusnurdilo, Manajemen Pondok Pesantren, 2003, hal.3), namun perkembangan jumlah lembaga Pondok Pesantren berkembang sangat signifikan menurut hasil penelitian Sartono Kartodirdjo (1985) tahun 1860 an jumlah Pondok Pesantren terutama di Jawa mencapai 300 buah, dan menurut data Departemen Agama pada tahun 1977 jumlah Pondok Pesantren mencapai 4.195 buah dengan jumlah santri 677.394 dan sangat mengejutkan pada tahun 2001 jumlah Pondok Pesantren mencapai 11.312 buah dengan jumlah santri 2.737.805 orang sungguh menunjukkan kemajuan yang sangat luar biasa baik jumlah lembaga maupun jumlah santrinya (Sulthon, 2003).

Namun berbeda halnya dengan jumlah Pondok Pesantren yang ada di wilayah Kabupaten Rejang Lebong yang hanya berjumlah 5 lembaga, dengan rincian 4 Pesantren Aktif, dan 1 Pesantren baru memiliki izin operasional, dengan jumlah santinya yang berkisar antara 100 orang samapi dengan 200 orang setiap pesantren, karena itu menjadi sebuah pertanyaan kanapa pada beberapa daerah terutama di luar wilayah Kabupaten Rejang Lebong dan cendrung juga di luar Provinsi Bengkulu yang mayoritas penduduknya muslim begitu banyak lembaganya maupun santrinya. Dinamika yang cendrung gtatis ini tentu akan terjawab melalui penelitian yang penulis lakukan (radarpatpetulainews.com, 2016).

Data di atas dapat dirinci sebagai berikut, hingga kini baru ada 4 pondok pesantren (ponpes) yang aktif di Kabupaten Rejang Lebong (RL). Menurut Kepala Kantor Kementerian Agama (Kemenag) Kabupaten Rejang Lebong (RL), melalui Kepala Seksi Pekapontren Drs. Teguh Ati, M.Pd mengatakan, jumlah ini masih belum ideal. Sebab idealnya di 1 Kecamatan, minimal ada satu pondok pesantren.Empat pondok pesantren yang sudah beroperasi dan masih aktif yakni Ponpes Ar-Rahmah di Desa Air Meles Bawah Kecamatan Curup Timur, Pondok pesantren Muhammadiyah di Desa Kampung Delima Kecamatan Curup Timur.Kemudian Pondok pesantren Miftahul Janah di Desa Karang Jaya Kecamatan Selupu Rejang dan Pondok pesantren Hidayatullah di Desa Air Duku Kecamatan Curup Timur (TU Kemenag Rejang Lebong, 2017).

Selanjutnya, kemandirian Pondok Pesantren bisa dilakukan melalui pengembangan ekonomi yang selama ini sudah berjalan dengan baik. Namun, akan lebih baik apabila didahului berbasis penelitian, karena akan lebih terencana, terprogram, dan terarah sehingga berdampak positif 
terhadap keberhasilan pengembangan ekonomi di Pondok Pesantren, karena itu pengembangan ekonomi berbasis penelitian merupakan sebuah keniscayaan.

Dari berbagai uraian, sejarah, dan eksistensi dari Pondok Pesantren yang telah terurai di atas, menunjukkan bahwa Pondok Pesantren tersebut merupakan murni sebagai lembaga pendidikan yang membawa misi mencetak para ulama yang intelektual dan intelektual ulama. Kesimpulan tersebut tidaklah sama halnya dengan pemberitaan dan sebagian fakta bahwa lembaga yang namanya Pondok Pesantren mendapatkan stempel dari sebagian oknum bahwa di Pondok Pesantren tempat mencetak paham radikal, teroris, dan berbagai macam gelar yang menyududutkan lembaga Pondok Pesantren tersebut. Sehingga gerak- gerik, sepak-terjang Pondok Pesantren menjadi suatu hal yang perlu diawasi oleh aparat. Hal tersebut menjadi mengemuka tidak sedikit oknum teroris yang sempat tertangkat dan dieksekusi seperti Amrozi pada tahun 2008, Dr. Azhari tahun 2005 dalam penyergapan oleh pihak kepolisian / DENSUS 88 Polri anti teror, dan beberapa kasus serupa lainnya. Karena itu penulis telah melakukan peran pondok pesantren dalam mencegah paham radikalisme di Kabupaten Rejang Lebong.

\section{METODE PENELITIAN}

Penelitian ini tergolong
sebagai penelitian lapangan atau field
research, yaitu peneliti melakukan

penelitian langsung di lokasi untuk mendapatkan dan mengumpulkan data.

Jenis penelitian ini adalah kualitatif, yakni penelitian yang dimaksudkan untuk memahami fenomena tentang apa yang dialami oleh subjek penelitian dan menghasilkan data deskriptif berupa kata-kata yang tertulis atau lisan dari orang-orang dan perilaku yang diamati (Moleong, 2012). Dengan begitu, dapat dikatakan bahwa penelitian ini bersifat deskriptif kualitatif. Artinya, penulis menganalisis dan menggambarkan penelitian secara objektif dan mendetail untuk mendapatkan hasil yang akurat.

Secara teoretis, penelitian deskriptif adalah penelitian yang bermaksud untuk mengumpulkan informasi mengenai status suatu gejala yang ada, yaitu keadaan gejala menurut apa adanya pada saat penelitian dilakukan, sehingga hanya merupakan penyingkapan fakta dengan menganalisis data (Arikunto, 2007). Penelitian ini memberikan suatu deskripsi atau gambaran tentang peran pondok pesantren dalam mencegah paham radikalisme di Kabupaten Rejang Lebong. Subjek Penilitian ini sesungguhnya dibawah payung metode kualitatif.Informan penelitian ini dibagi menjadi informan kunci dan informan pelengkap. Informan dalam penelitian ini antara lain; Kyai Pondok Pesantren, Kurikulum Pondok Pesantren, sedangkan informan lainnya adalah orang-orang 
yang terlibat dalam pendidikan karakter di pondok pesantren. Ada dua jenis data dikategorikan berdasarkan fungsinya, yakni data primer dan data sekunder.Adapun teknik pengumpulan data yang dilakukan dalam penelitian ini adalah :1). Wawancara yang dilakukkan dalam penelitian ini adalah wawancara mendalam, karena dengan begitu peneliti akan mendapatkan informasi yang dibutuhkan dalam menyusun penelitian ini. Wawancara terbagi dua bagian yaitu wawancara terstruktur dan wawancara tak berstruktur.Teknik ini biasanya digunakan dalam penelitian kualitatif karena selain bersifat luwes, susunan pertanyaan dan kata-kata dapat diubah sesuai dengan kebutuhan dan kondisi saat wawancara) peneliti dapat memperoleh bentuk-bentuk tertentu informasi. 2). Observasi dan teknik pengumpulan data yang lain (wawancara dan studi dokumentasi) adalah cara untuk mendapatkan data lapangan yang baik. Data lapangan adalah apa yang pengalaman peneliti , dan apa yang dicatat dalam catatan lapangan dan menjadi bahan untuk di analisis secara sistematis. Menurut W. Laurence Neuman observasi adalah; apa yang peneliti lakukan dilapangan untuk memberikan perhatian, mengamati, dan mendengarkan dengan seksama. Peneliti menggunakan semua inderanya, melihat apa yang dilihat, mendengar, mencium bau, mengecap, atau menyentuh. Peneliti menjadi instrumen yang menyerap semua sumber informasi (Lawrence, 1991).
3). Dokumentasi, dimana peneliti melakukan penghimpunan data-data berupa dalam bentuk regulasi, dokumen-dokumen yang relevan, dan lain-lainnya untuk dijadikan bahan pendukung dalam mengolah data dari lapangan. Teknik ini digunakan untuk memperoleh data dan informasi yangn dibutuhkan dalam penelitian ini dengan cara studi pustaka terhadap buku-buku dan dokumen lain yang relevan.

\section{HASIL DAN PEMBAHASAN}

\section{Profil Pondok Pesantren Muhammadiyah}

Pondok

Pesantren

Muhammadiyah dengan nomor Statistik 5121702030002 berlokasi di Desa Kampung Delima Kecamatan Curup Timur Kabupaten Rejang Lebong yang berdiri pada tahun 1988 yang sekarang ini dipimpin oleh Joni Antoni, S.Pd.I. Dapat diungkap dalam beberapa informasi antara lainnya :

\section{Sejarah dan Perkembangannya}

Keberadaan Muhammadiyah di Curup dimulai pada tahun 1928 yang telah membuat amal usaha antara lain Sekolah Rakyat Muhammadiyah (SD) dan PGA IV tahun Muhammadiyah, dalam perkembangannya PGA dihapuskan oleh pemerinyah pada tahun 1978, kemudian gedung tersebut dimanfaatkan untuk program SMP dan SMA Muhammadiyah. Sejalan dengan waktu perkembangan berikutnya Muhammadiyah mendapat wakaf di daerah Tempel Rejo Kecamatan Curup Selatan berupa tahan dan satu unit bangunan gedung berikut kantor dan musholla dan satu 
bidang sawah dimanfaatkan untuk kesejahteraan guru-guru, maka SMP dan SMA pindah ke Tempel Rejo dan Gedung PGA lama menjadi kosong. Dengan kesepakatan Pimpinan Daerah Muhammadiyah dan Pimpinan Cabang Muhammadiyah pada tahun 1988 mendirikanlah pondok pesantren Muhammadiyah dengan memanfaatkan gedung PGA IV tahun yang lama tersebut.

Pondok

Pesantren

Muhammadiyah adalah potren sebuah lembaga pendidikan yang tengah berjuang untuk eksis, sebagai salah satu amal usaha Muhammadiyah khususnya di bidang pendidikan. Dalam rangka meneruskan amanah perjuangan pendiri Muhammadiyah KH. Ahmad Dahlan, pada tahun 1990 dalam musyawarah Wilayah Muhammadiyah Bengkulu, maka dikukuhkan sebagai satu-satunya pondok pesantren pembinaan Muhammadiyah Provinsi Bengkulu.

Dari waktu ke waktu Pondok Pesantren Muhammadiyah terus berbenah diri dalam mengikuti perkembangan zaman khususnya dalam upaya mewujudkan manusia yang utuh yaitu ulama yang intlek dan intlek ulama, baik pada sisi ilmu pengetahuan agama, maupun ilmu pengetahuan umum, serta mampu mengikuti kemajuan teknologi sesuai dengan perkembangan zaman. Sehingga kini Pondok Pesantren Muhammadiyah Curup telah meluluskan siswa untuk tingkat MTs 20 angkatan dan Aliyah 13 angkatan, serta SMK 2 angkatan.
Pada tahun 2001 Pondok Pesantren Muhammadiyah memfokuskan pada pembangunan kampus baru pondok yang berlokasi di tempat yang sama telah membangun dua local belajar, pada tahun 2002 membangun empat lokal belajar, pertengahn tahun 2002 mendapat bantuan dua local lagi serta bantuan dari Ahmad Ferial Husen dari Jakarta sebanyak satu unit asrama enam local, pertengahan tahun 2003 membangun kembali dua local asrama bantuan dari pemerintah, dan pada tahun 2004 mendapat bantuan satu unit masjid dari keluarga almarhum Rustam Ilyas.

Kondisi Masyarakat lingkungan

Lokasi Pondok Pesantren Muhammadiyah Curup yang berlokasi di jalan Syahrial Desa Kampung Delima Kecamatan Curup Timur Kabupaten Rejang Lebong adalah suatu lokasi yang dapat dikatakan sangat strategis. Berada dekat dengan pusat kota Kabupaten Rejang Lebong yang hanya berjarak lebih kurang $2 \mathrm{KM}$, transportasi lancer, udara yang sejuk, jauh dari kebisingan, tenang, nyaman, aman dari berbagai gangguan, berdekatan dengan pemukiman penduduk yang mayoritas berasal dari suku Jawa.

Kondisi social ekonomi masyarakat sekitar sangat beragam demikian pula profesinya, namun yang sangat dominan adalah sebagai petani, buruh, pekerja swasta, dan mayoritas pemeluk agama Islam.

Program Pendidikan

Pondok

Pesantren

Muhammadiyah

Curup 
menyelenggarakan dua jenis pendidikan yaitu pendidikan formal agama (Madrasah) dan pendidikan formal umum (Sekolah). Pendidikan formal agama menyelenggarakan tingkat Madrasah Tsanawiyah (MTs), dan Madrasah Aliyah (MA) dengan kurikulum tahun 2013 sebagai intrakurikuler dan kurikulum pondok pesantren merupakan kurikulum tambahanatau kokurikuler seperti; pengajian kitab diselenggarakan secara rutin mulai ba'da zuhur, ba'da magrib dan ba'da subuh dengan materi; Hadist, Fiqh Ibadah, Bahasa Arab dan Inggris, muhadharah, kaligrafi, tahfidzul quran, dan tahsinul qira'ah. Sedangkan ektrakurikuler seperti; Pramuka, Tapak Suci (TS), sanggar, nasyid, dan olah raga seperti; sepak takrau, futsal, volley ball, serta tenis. Selanjutnya karena kapasitas asrama untuk santriwan-santriwati belum mampu menampung semuanya, maka bagi santri yang berasal dari masyarakat sekitar diperbolehkan untuk tinggal di rumah masing-masing dan yang berasal dari jauh ditampung pada asrama yang tersedia.Sedangkan pada pendidikan pada sector pendidikan formal umum yaitu SMK diberikan kurikulum tahun 2013 dan tidak diberi tambahan kurikulum pondok pesantren, tetapi ektrakurikuler diberi kesempatan yang sama.

\section{Sarana dan Prasarana serta Sumber Dana}

Sarana dan prasarana yang dimiliki Pondok Pesantren berupa 11 ruang belajar, ruang kantor, ruang guru, ruang perpustakaan, ruang laboratorium, ruang keterampilan, asrama putra dan putrid, masjid 1 unit, rumah pimpinan pondok pesantren, dan empat rumah ustaz, 10 MCK, serta sarana olah raga berupa; lapangan futsal, basket, volley ball, takrau, dan tenis meja, sedangkan sumber air bersih dari sumur tanah.

Sementara itu untuk sumber dana diperoleh dari sumbangan wali santri atau spp, donator dan bantuan pendidikan dari pemerintah, serta hasil pengolahan lahan berupa tanaman palawija. Selain itu pondok pesantren ada program LM3 bermitra dengan masyarakat di sekitar pondok pesantren yaitu mengembangkan usaha pengembangbiakan sapi, yang sekarang sudah berjumlah 12 ekor sapi.

Peran Pondok Pesantren MuhammadiyahDalam Mencegah Paham Radikalisme di Kabupaten Rejang Lebong.Pondok Pesantren Muhammadiyah berkomitmen untuk mengembalikan pada tithahnya yaitu tafaqquh fiddin, dimana sejalan dengan eksistensi pondok pesantren dalam menciptakan ulama yang ilmuan dan ilmuan ulama. Seiring dengan kemajuan yang pesat serta ketertarikan orang terhadap lembaga pondok pesantren lebih-lebih dalam perkembangan yang dikaitkan dengan kondisi perpolitikan dewasa ini di Indonesia dimana pondok pesantren menjadi menarik dan seksi, namun pondok pesantren Muhammadiyah tetap tidak mau ditarik-tarik ke politik praktis.

Ketika

komitmen mempertahankan titahnya pondok 
pesantren sebagai tafaqquh fiddin, maka peran pondok pesantren tersebut akan mampu mencegah paham radikalisme karena tidak dibukanya peluang untuk berekpresi mulai dari para pengelola pondok pesantren, ustaz, kiyai, dan para civitas pondok pesantrennya termasuk santriwan/santriwatinya.

Kita tidak sedikit mengetahui dan mendengar orang-orang tertentu berupaya menarik pondok pesantren mulai dari secara kelembagaan maupun secara individu kearah kelompok atau partai tertentu. Hal demikian tidak dapat dipungkiri disamping tidak sedikit nama-nama besar di negeri ini yang keluar dari perut pondok pesantren, disamping itu jumlah lembaganya yang tidak sedikit berikut para Kiyai dan santrinya pun tidak sedikit, bahkan yang cendrung lebih menarik lagi budaya mayoritas di pondok pesantren senantiasa manut apa yang diinstruksikan oleh Kiyai nya yang demikian lahan empuk bagi pihat yang berkepentingan untuk meraup suara pada Pilleg maupun Pilpres 2019. Bahkan lebih menarik lagi akhir-akhir ini Wakil Ketua KomisiVIII DPR RI Noor Ahmad mengusulkan kepada Kementerian Agama RI agar Ditjen Pendidikan Islam dipecah menjadi 3 Ditjen yaitu Ditjen Pendidikan Tinggi Islam, Ditjen Pesantren, dan Ditjen Madrasah. Idea yang demikian ini dapat dipahami bahwa secara politis pihak tertentu ingin memperlihatkan perhatian (ection) terhadap dunia pendidikan tertua di Indonesia ini agar mau digaet untuk mendulang suara pada iven Pilleg dan Pilpres mendatang.

Karena itu menutut Antoni manajemen revitalisasi Pondok Pesantren Muhammadiyah adalah bagaimana civitas Pondok Pesantren senantiasa komitmen terhadap eksistensi pondok pesantren dari sejak dahulu yaitu bertujuan untuk menciptakan Kiyai yang ilmuan dan ilmuan Kiyai (tafaqquh fiddin). Hal tersebut sejalan dengan komitmen Pimpinan Pusat Muhammadiyah bahwa Muhammadiyah netral dalam iven Pilleg dan Pilpres 2019 nanti, karena menurut Antoni antara tafaqquh fiddin dengan politik praktis itu adalah dua yang berbeda dan Pondok Pesantren tidak mau lebai ikut-ikutan yang tidak sesuai dengan peran pondok pesantren semenjak lahirnya hingga sekarang.

Profil Pondok Pesantren Miftahul Jannah, Sejarah dan Perkembangan

Pondok pesantren Miftahul Jannah yang berlokasi di Desa Karang Jaya Kecamatan Selupu Rejang Kabupaten Rejang Lebong dengan nomor statistic : 510017020004 dengan tahun berdirinya pada tahun 2007. Pondok Pesantren Miftahul Jannah dalam sejarahnya adalah berasal dari pondok pesantren Nurul Kamal, yang berawal dari gagasan dan permintaan bapak Abdul Mu'in kepada bapak Waras Santoso (Bupati Rejang Lebong) ketika acara peresmian masjid Miftahul Jannah di Desa Karang Jaya pada tahun 1988 . 
Satu bulan setelah peresmian itu, gagasan dan permintaan pendiri pondok pesantren tersebut di kabulkan oleh Bupati Rejang Lebong dengan mencari lokasi sekitar masjid dengan cara membeli atau ganti rugi atas tanah milik warga sekitar 2 hektar. Akhirnya pada tahun 1989, pembangunan pondok pesantren selesai dan diresmikan oleh pangdam II Seriwijaya yaitu Tri Sutresno, serah terima kepada bapak Abdul Mu'in.

Untuk legalitas pondok pesantren maka dibentuklah yayasan "Nurul Kamal" selanjutnya disusun badan pendiri dan pengurus yang terdiri dari para pejabat Pembda dan Departemen terkait serta beberapa tokoh masyarakat. Kemudian susunan kepengurusan diserahkan kepada pihak membuat akta notaries.

Sebagai langkah awal selain program pondok pesantren, pihak yayasan dengan nama Nurul Kamal mendirikan :Taman kanak-kanak Nurul Kamal, Madrasah Ibtidaiyyah Nurul Kamal, Madrasah Tsanawiyah Nurul Kamal, dan Madrasah Aliyah Nurul Kamal.

Program-program pendidikan tersebut mandapat sambutan masyarakat Rejang Lebong, sehingga santri, santriwati pondok pesantren yayasan Nurul Kamal cukup banyak.Masa keemasan pondok pesantren Nurul Kamal ternyata tidak lama, hal ini diawali setelah bapak Waras Santoso (selaku Pendiri pondok pesantren) sehabis masa jabatannya sebagai bupati Rejang Lebong. Sedangkan badan pengurus tidak dapat melaksanakan tugasnya dan kewajiban untuk mengembangkan pesantren, bahkan pondok pesantren menjadi kepentingan pribadi dan kelompok tertentu. Kondisi ini dibuktikan dengan :Sering bergantinya kiyai dan pengasuh pondok pesantren, Semakin berkurangnya santri (karena hilangnya kepercayaan masyarakat), Fasilitas yang tidak terawat dan tidak berkembang, Berhentinya oprasi madrasah Aliyah Nurul Kamal pada tahun 1991/1992.

Kondisi tersebut mengesankan bahwa pondok pesantren tidak ada tuannya bahkan kepengurusan Yayasan senantiasa berganti-ganti tapi tidak ada taunnya dan tidak ada perubahan kinerja Yayasan Nurul Kamal seperti pepatah "Mati Segan Hidup Takmau”, merupakan ungkapan yang tepat untuk menggambarkan kondisi pondok pesntren Nurul Kamal.

Melihat keterpurukan yang sangat lama dan potensi yang di tinggal, diawali dengan perbincangan dengan tokoh masyarakat, tokoh agama dan perangkat desa karang jaya. Maka pada tanggal 8 februari 2007 diadakan pertemuan di ruang pola Pemda Rejang Lebong yang dihadiri Bapak Bupati Rejang Lebong (Suherman SE), Kepala Kementrian agama, Ketua MUI, pihak Yayasan Nurul Kamal dan Kades Desa Karang Jaya serta tokoh masyarakat dan tokoh agama desa Karang Jaya.

Pertemuan

tersebut

menghasilkan :Pesantren dikembalikan kedesa Karang Jaya, 
Segera dibentuk badan pengelola pondok pesantren, Pihak yayasan Nurul Kamal (H.Yunus Ali) menyatakan uji coba selama tiga tahun, jika terbukti pengelola berhasil maka Yayasan Nurul Kamal dan asetnya diserahkan Kepada Desa Karang Jaya.Langkah awal yang dilakukan :Membentuk badan pengelola pondok pesantren dengan diketahui oleh KH.Abdul Mu'in, Mengganti nama pesantren Nurul Kamal, menjadi pondok pesantren Miftahul Jannah, Mengkoordinir dan memfasilitasi lembaga pendidikan yang sudah ada (TK dan MI), Mendirikan Madrasah Diniyah, Mendirikan SMP Islam Terpadu Miftahul Jannah, Merehab dan menambah bangunan dengan dana yang masih terbatas.

\section{Kondisi Masyarakat.}

Lokasi Pondok Pesantren Miftahul Jannah Curup yang berlokasi di Desa Karang Jaya Kecamatan Selupu Rejang Kabupaten Rejang Lebong adalah suatu lokasi yang dapat dikatakan sangat strategis karena berada di tengah pemukiman masyarakat yang cukup padat walau jauh dari pusat kota Kabupaten, namun transportasi lancer, udara yang sejuk, jauh dari kebisingan, tenang, nyaman, aman dari berbagai gangguan, areal pondok pesantren cukup luas yang dikelilingi pemukiman penduduk yang mayoritas berasal dari suku Jawa.Kondisi social ekonomi masyarakat sekitar sangat beragam demikian pula profesinya, namun yang sangat dominan adalah sebagai petani, pedagang, pekerja swasta, dan mayoritas pemeluk agama Islam.

\section{Program Pendidikan}

Yayasan Nurul Kamal/ Pondok Pesantren Miftahul Jannah mengelola berbagai jenis pendidikan non formal dan formal yang bertujuan agar parasantri dan santri wati dapat menempuh di dalam segala bidang pendidikan baik pendidikan formal yang dapat digunakan untuk melanjutkan ke pendidikan yang tinggi dan pendidikan non formal sebagai modal untuk bekal dalam kehidupan sehari-hari yang berkecipung dalam masyarakat berupa pendidikan agama. Adapun pendidikan yang diprogramkan oleh pondok pesantren adalah :Program pendidikan formal berupa; Taman Kanak-Kanak (TK), Madrasah Ibtidaiyah (MI), SMP Islam Terpadu, dan Madrasah Aliyah dengan jumlah santri/murid 290 orang. Sedangkan program pendidikan nonformal ; Taman Pendidikan Alquran (TPQ) dan Madrasah Diniyah dengan jumlah santrinya 119 orang.

\section{Sarana dan Prasarana serta} Sumber Dana.

Sarana dan prasarana yang dimiliki Pondok Pesantren Miftahul Jannah merupakan aset lama dan baru yang terdiri dari ; Bangunan SMP dan TK, ruang belajar Madrasah Ibtidaiyah, ruang belajar Madrasah Tsanawiyah, ruang belajar Aliyah, ruang kantor, ruang guru, asrama putra, asrama putri, ruangan yayasan, ruang, rumah ustaz, dan gedung Puskestren. Sementara untuk kelangsungan proses berbagai 
program sumber dana berasal dari SPP santri, donator baik dari masyarakat sekitar mapun pihakpihak yang perduli.

Peran Pondok Pesantren Miftahul Jannah Dalam Mencegah Paham Radikalisme di Kabupaten Rejang Lebong.

Peran Pondok Pesantren Miftahul Jannah memang dibutuhkan komitmen untuk mengembali kan pada tithahnya yaitu tafaqquh fiddin, dimana sejalan dengan kemajuan yang pesat serta ketertarikan orang terhadap lembaga pondok pesantren lebih-lebih dalam perkembangan yang dikaitkan dengan kondisi perpolitikan dewasa ini di Indonesia dimana pondok pesantren menjadi menarik dan seksi.

Karena itu tidak sedikit orangorang tertentu berupaya menarik pondok pesantren mulai dari secara kelembagaan maupun secara individu kearah kelompok atau partai tertentu. Hal demikian tidak dapat dipungkiri disamping tidak sedikit nama-nama besar di negeri ini yang keluar dari perut pondok pesantren, disamping itu jumlah lembaganya yang tidak sedikit berikut para Kiyai dan santrinya pun tidak sedikit, bahkan yang cendrung lebih menarik lagi budaya mayoritas di pondok pesantren senantiasa manut apa yang diinstruksikan oleh Kiyai nya yang demikian lahan empuk bagi pihat yang berkepentingan untuk meraup suara pada Pilleg maupun Pilpres 2019. Bahkan lebih menarik lagi akhir-akhir ini Wakil Ketua Komisi VIII DPR RI Noor Ahmad mengusulkan kepada Kementerian Agama RI agar Ditjen Pendidikan Islam dipecah menjadi 3 Ditjen yaitu Ditjen Pendidikan Tinggi Islam, Ditjen Pesantren, dan Ditjen Madrasah. Idea yang demikian ini dapat dipahami bahwa secara politis pihak tertentu ingin memperlihatkan perhatian (ection) terhadap dunia pendidikan tertua di Indonesia ini agar mau digaet untuk mendulang suara pada iven Pilleg dan Pilpres mendatang.

Karena itu menutut $\mathrm{Mu}$ 'in manajemen revitalisasi Pondok Pesantren Miftahul Jannah agar berperan dalam mencegah paham radikalisme adalah bagaimana civitas Pondok Pesantren senantiasa komitmen terhadap eksistensi pondok pesantren dari yang sejak dahulu yaitu bertujuan untuk menciptakan Kiyai yang ilmuan dan ilmuan Kiyai dan sering juga disebut orang (tafaqquh fiddin) karena sesuai dengan titahnya.

\section{Profil Pondok Pesantren Ar- Rahmah}

\section{Sejarah dan Perkembangan}

Pondok Pesantren Ar-Rahmah adalah lembaga tafaqquh fiddin dan dakwa yang terletak di Desa Air Meles atas Kecamatan Selupu Rejang Kabupaten Rejang Lebong dengan Nomor Statistik : 5.1.0.0.17.02.000, lokasi pondok Pesantren Ar-Rahmah dapat dikatakan cukup startegis berada tidak jauh dari pusat Kota Kabupaten yang hanya berjarak sekitar 3 KM lokasinya agak memojok kedalam setelah melewati pemukiman pada penduduk dengan 
mayoritas muslim yang didominasi dari suku Jawa. Dalam sejarahnya mula-mula pesantren ini di kenal dikhalayak publik, atau lebih di kenal dengan lembaga pengkajian nilai-nilai agama serta dakwa Islam. Kurikulumnyapun berorientasi pada pengkajian dan pemahaman ajaranajaran agama, maka pesanterinilah yang melahirkan output yang akan menjadi tokoh agama, kiayi, ustadz, dengan kemampuan dan pemahaman agama yang mempuni.

Namun, dalam perjalanan waktu yang diiringi dengan pesatnya perkembangan dan kemajuan IPTEK, layanan informasi dan komputerisasi lewat dunia maya yang tidak dapat terfilter.Watak kemandirian yang menjadi ciri khas pesantren sebagai lembaga pembeda dengan lembagalembaga pendidikan lainnya mulai tergeser. Dengan tidak menafikan motivasi ibadah dalam proses belajar, pesantren juga dituntut mengapresiasi serta selektif dalam merespon perkembangan dunia. Tuntutan faktual hidup itulah yang membuat pesantren suka tidak suka harus lebih realistis dalam menghadapi tuntutan tersebut.

Pondok Pesantren Ar-Rahmah berdiri tahun 1990 dibawah Yayasan Pendidikan Islam Ar-Rahmah dengan akte notaris tahun 1990, secara kontinyu dan simultan terus melakukan pembenahan dan pengembangan, baik pengembangan yang berbentuk fisik maupun non fisik. Pemberdayaan masyarakat dibidang keilmuan tidak diragukan lagi, terutama dalam menunjang program pemerintah tentang Wajib Belajar Sekolah Dasar Sembilan Tahun, disamping terus melakukan pembinaan keIslaman ditengahtengah masyarakat.Peran Pondok Pesantren ini dalam hal pembinaan dan pengembangan intelektual dibuktikan dengan diraihnya perestasi beasiswa selama kuliah oleh alumni pondok pesantren Ar-Rahmah tahun 2007 di IAIN Semarang.

Untuk meningkatkan gairah pendidikan dan pengajaran di pondok pesantren Ar-Rahmah terus bergelora dalam upaya meraih mutu dan kualitas yang diharapkan, tentu sangat perlu didukung dengan sarana dan prasarana yang memadai, sehingga dapat menciptakan suasana kondusif dalam pelaksanaan program pendidikan dan pengajaran. Untuk itu diperlukan media pengajaran, perlengkapan penataan ruang belajar, ATK penunjang tenaga didik dan kependidikan, dan penunjang kegiatan ekstrakulikuler.

Keberadaan Pondok Pesantren Ar-Rahmah seperti dikemukakan di atas adalah semula merupakan tempat dan wadah pengkajian ilmu dan hokum agama Islam, lalu berkembang menjadi lembaga Pondok Pesantren Ar-Rahmah. Pada perkembangan selanjutnya Pondok pesantren Arrahmah menyelenggarakan sistem pendidikan klasikal menjadi satuan dalam Tarbiyatul Mu'allimin Walmu'amillat Al-Islamiyah (TMI) masa belaja selama 6 (enam) tahun, terdiri tingkatan: Madrasah Tsanawiyah Ar-Rahmah (MTs) Terakreditasi, Madrasah Aliyah Ar- 
Rahmah (MAS) Terakreditasi, dan Madrasah ibtidaiyah Ar-Rahmah (MIS). Santri Pondok Pesantren ArRahmah setelah menyelesaikan pendidikannya diberikan 2 (dua) ijazah yaitu Syahadah Pondok / Ijazah Pondok dan Surat Tanda Tamat Belajar (STTB) tingkat MA/MTs.

\section{Kondisi Masyarakat lingkungan}

Lokasi Pondok Pesantren ArRahmah yang berada di Desa Air Meles Atas Kecamatan Selupu Rejang ini, tidak terlalu jauh dengan pusat kota Kabupaten Rejang Lebong yang hanya berjarak lebih kurang 3 $\mathrm{KM}$, transportasi lancer, udara yang sejuk, jauh dari kebisingan, tenang, nyaman, aman dari berbagai gangguan, berdekatan dengan pemukiman penduduk yang mayoritas berasal dari suku Jawa.

Kondisi social ekonomi masyarakat sekitar sangat beragam demikian pula profesinya, namun yang sangat dominan adalah sebagai petani, sebagian kecil sebagai peternak, buruh, pekerja swasta, dengan mayoritas pemeluk agama Islam.

\section{Program Pendidikan}

Pondok Pesantren Ar-Rahmah Curup menyelenggarakan pendidikan Madrasah Ibtidaiyah (MIS), Madrasah Tsanawiyah Ar-Rahmah (MTs) Terakreditasi, dan Madrasah Aliyah (MA) terakreditasi. Selanjutnya dalam menjalankan program kurikulum pondok pesantrennya diselenggarakan dapa sore dan malam harinya yang merupakan kokurikuler berupa; pengajian kitab diselenggarakan secara rutin mulai ba'da zuhur, ba'da magrib dan ba'da subuh dengan materi; Hadist, Fiqh Ibadah, Bahasa Arab dan Inggris, muhadharah, kaligrafi, tahfidzul quran, dan tahsinul qira'ah. Sedangkan ektrakurikuler seperti; kursus menjahit, Pramuka, Tapak Suci (TS), sanggar, nasyid, dan olah raga seperti; sepak takrau, futsal, volley ball, serta tenis. Selanjutnya karena kapasitas asrama untuk santriwan-santriwati belum mampu menampung semuanya, maka bagi santri yang berasal dari masyarakat sekitar diperbolehkan untuk tinggal di rumah masing-masing dan yang berasal dari jauh ditampung pada asrama yang tersedia.

\section{Sarana dan Prasarana serta Sumber Dana}

Sarana dan prasarana yang dimiliki Pondok Pesantren berupa; Masjid 1 unit, asrama putra dan putri 11 unit, ruang kelas 9 unit, dapur umum 1 unit, ruang informasi 1 unit, ruang perpustakaan 1 ruangan, MCK, 5 unit, ruang kursus 1 unit, perumahan guru 8 unit, rumah pimpinan 1 unit, ruang UKS 1 unit, ruang konseling 1 unit, ruang kantor 1 unit, dan ruang tamu 1 unit, serta gedung Puskestren 1 unit.Sementara itu lapangan olah sarana olah raga berupa; lapangan futsal, volley ball, takrau, dan tenis meja, sedangkan sumber air bersih dari sumur tanah.

Sementara itu untuk sumber dana diperoleh dari sumbangan wali santri atau spp, donator dan bantuan pendidikan dari pemerintah, serta hasil pengolahan lahan berupa tanaman palawija. Selain itu pondok 
pesantren ada program LM3 bermitra dengan masyarakat di sekitar pondok pesantren yaitu mengembangkan usaha pengembangbiakan sapi, yang sekarang sudah berjumlah 12 ekor sapi.

\section{Peran Pondok Pesantren Ar-} RahmahDalam Mencegah Paham Radikalisme Kabupaten Rejang Lebong.

Peran Pondok Pesantren ArRahmah memang dibutuhkan komitmen untuk mengembali kan pada tithahnya yaitu tafaqquh fiddin, dimana sejalan dengan kemajuan yang pesat serta ketertarikan orang terhadap lembaga pondok pesantren lebih-lebih dalam perkembangan yang dikaitkan dengan kondisi perpolitikan dewasa ini di Indonesia dimana pondok pesantren menjadi menarik dan seksi.

Karena itu tidak sedikit orangorang tertentu berupaya menarik pondok pesantren mulai dari secara kelembagaan maupun secara individu kearah kelompok atau partai tertentu. Hal demikian tidak dapat dipungkiri disamping tidak sedikit nama-nama besar di negeri ini yang keluar dari perut pondok pesantren, disamping itu jumlah lembaganya yang tidak sedikit berikut para Kiyai dan santrinya pun tidak sedikit, bahkan yang cendrung lebih menarik lagi budaya mayoritas di pondok pesantren senantiasa manut apa yang diinstruksikan oleh Kiyai nya yang demikian lahan empuk bagi pihat yang berkepentingan untuk meraup suara pada Pilleg maupun Pilpres 2019. Bahkan lebih menarik lagi akhir-akhir ini Wakil Ketua Komisi VIII DPR RI Noor Ahmad mengusulkan kepada Kementerian Agama RI agar Ditjen Pendidikan Islam dipecah menjadi 3 Ditjen yaitu Ditjen Pendidikan Tinggi Islam, Ditjen Pesantren, dan Ditjen Madrasah. Idea yang demikian ini dapat dipahami bahwa secara politis pihak tertentu ingin memperlihatkan perhatian (ection) terhadap dunia pendidikan tertua di Indonesia ini agar mau digaet untuk mendulang suara pada iven Pilleg dan Pilpres mendatang.

\section{SIMPULAN}

Peran Pondok Pesantren di Kabupaten Rejang Lebong dalam mencegah paham radikalisme sangat efektif melalui pengontrolan yang ketat terhadap civitas pondok pesantren;

Komitmen pimpinan pondok pesantren untuk konsekwen menempatkan eksistensinya sebagai tafaqquh fiddinkonci terciptanya pondok pesantren yang selalu konsen dalam mendalami keilmuan agama di Kabupaten Rejang Lebong;

\section{DAFTAR PUSTAKA}

Arikunto, S. (2007). Manajemen Penelitian. Jakarta: Rineka Cipta.

Bagian Tata Usaha/Data dan Informasi Kantor Kementerian Agama Kabupaten Rejang Lebong, observasi tanggal 25 September 2017

Fathurrochman, I. (2017). Implementasi Manajemen Kurikulum Dalam Upaya 
Meningkatkan Mutu Santri Pondok Pesantren Hidayatullah/Panti Asuhan Anak Soleh Curup. TADBIR : Jurnal Studi Manajemen Pendidikan, [S.1.], v. 1, n. 1, p. 85-104, june 2017. ISSN 25805037. Available at: $<$ http://journal.staincurup.ac.id/i ndex.php/JSMPI/article/view/21 6> . Date accessed: 27 feb. 2018.

doi:http://dx.doi.org/10.29240/j smp.v1i1.216.

http://www.radarpatpetulainews.com/ 2016/05/baru-ada-4-ponpesaktif-di-rejang-lebong.html, diakses tanggal 29 September 2017.

Asmani J., M. (2012). Buku Panduan Internalisasi Pendidikan Karakter diSekolah.

DIVAPress: Yogyakarta

Kamus Besar Bahasa Indonesia, (Online).

(http://http://kbbi.web.id/pola, diakses 20 Mei 2015) 2015

Kartodirdjo, S. (1985) Ratu Adil. Jakarta: Sinar Harapan

Mantu, R. (2015). Bina-Damai Dalam Komunitas Pesantren: Sebuah Upaya Counter-Radikalisme. Walisongo: Jurnal Penelitian Sosial Keagamaan. Vol 23, No 1 (2015). ISSN: 0852-7172 (p) 2461-064X (e).Available at: <http://akademik2.walisongo.ac .id/ejournal/index.php/walisong o/article/view/227 >. Date accessed: 10Desember. 2017. doihttp://dx.doi.org/10.21580/w s.23.1.227.

Masamah, U. (2014). Pesantren dan pendidikan perdamaian. Jurnal Pendidikan Islam, [S.1.], v. 2, n. 1, p. 21-39, sep. 2014.ISSN 2356-3877. Available at: $<$ http://ejournal.uinsuka.ac.id/tarbiyah/index.php/J PI/article/view/1126>. Date accessed: 27 feb. 2018. doi: http://dx.doi.org/10.14421/j pi.2013.21.21-39.

Moleong, L., J. (2014). Metodologi Penelitian Kuantitati. Bandung: Remaja Rosdakarya

Pondok Pesantren Makamhaji Surakarta,Sekilas Kurikulum Pondok Pesantren Al Muayyad Windan, ditetapkan 23 Agustus2007 M/10 Sya'ban 1428 H di Windan, Makamhaji Kartasura, Sukoharjo.

Puslitbang Kementerian Agama RI, 2011

Sulthon, M \& Khusnurdilo, M. (2003). Manajemen Pondok Pesantren. hal.1.

W. Lawrence Neuman. (1991). Social Research Methods: Qualitative and Quantitative Approaches Fifth Edition, (USA, Pearson Education:), h. 381 